\title{
Debido proceso probatorio en el procedimiento sancionatorio contractual en Colombia
}

\author{
Diana Lorena Mateus Londoño ${ }^{1}$
}

\section{RESUMEN}

El debido proceso es un principio rector de los procedimientos sancionatorios contractuales. Sin embargo, el procedimiento sancionatorio consagrado en el estatuto anticorrupción de 2011 no señala cómo se deben adelantar las etapas de conformación del material probatorio, su práctica y su valoración dentro del mencionado trámite. La falta de claridad sobre las garantías y derechos probatorios de los contratistas puede resultar lesiva para estos últimos, máxime cuando la autoridad decisoria actúa como juez y parte. Haciendo uso de la función integradora de las garantías y principios mínimos que envuelve el derecho fundamental al debido proceso, la investigación realiza un análisis de aquellas con que cuenta el contratista en el marco de este trámite, y con particulares consideraciones al informe de la interventoría o del supervisor del contrato que debe allegarse con la citación al procedimiento.

Palabras clave: proceso sancionatorio contractual, debido proceso probatorio, garantías probatorias, garantías procesales, derecho contradicción probatoria, derecho de defensa.

1 Máster en Razonamiento Probatorio de la Universidad de Girona, Girona, España. Abogada asociada de Azula Camacho Abogados y abogada de la Dirección de Transporte y Tránsito del Ministerio de Transporte, Bogotá, Colombia. Correo-e: dlorena.mateus@ gmail.com. Enlace ORCID: 0000000237190245 . Fecha de recepción: 1. ${ }^{\circ}$ de marzo de 2020. Fecha de modificación: 25 de abril de 2020. Fecha de aceptación: 2 de mayo de 2020. Para citar el artículo: Mateus Londoño, Diana LoREnA. "Debido proceso probatorio en el procedimiento sancionatorio contractual en Colombia", Revista digital de Derecho Administrativo, Universidad Externado de Colombia, n. ${ }^{\circ} 24,2020$, pp. 183-211. DOI: https://doi. org/10.18601/21452946.n24.08. 


\title{
Evidentiary Rules and Due Process in Contractual Sanctioning Procedures in Colombia
}

\begin{abstract}
Due process is a guiding principle of contractual sanctioning procedures. However, the sanctioning procedure prescribed in the Anticorruption Act of 2011 does not indicate the procedural steps for gathering evidence and assessing the evidentiary material. The lack of precision with regards to the procedural guarantees and rights may be harmful for contractors, especially when the decision-making authority is the contracting party. Since the fundamental right to due process comprehends a minimum of guarantees and principles, the research undertakes an analysis of those available to contractors, such as the attachment of the auditor or supervisor report to the subpoena.

Keywords: Contractual Sanctioning Procedure, Evidentiary Rules, Due Process Guarantees, Right to Contradict Evidence, Right of Defense.
\end{abstract}

\section{INTRODUCCIÓN}

El artículo 17 de la Ley 1150 de 2007 establece el debido proceso como principio rector de los procedimientos sancionatorios contractuales, y el artículo 86 de la Ley 1474 de 2011 reglamentó el procedimiento mínimo que deben cumplir las entidades públicas para imponer unilateralmente multas, sanciones, declaratorias de incumplimiento, tasación de perjuicios y hacer efectiva la cláusula penal en el marco de un contrato. La jurisprudencia y la doctrina nacional, por su parte, resaltan la necesidad que el contratista, contra quien se sigue un procedimiento sancionatorio contractual, tenga plena garantía del derecho de defensa, contradicción, y al debido proceso que consagra el artículo 29 de la Constitución Política de 1991.

En virtud del debido proceso administrativo, el contratista contra quien se adelanta esta clase de procedimiento cuenta con los siguientes derechos: a un procedimiento público, a la defensa y contradicción, a aportar pruebas y a contradecir las que se alleguen en su contra, que el procedimiento se adelante ante la autoridad competente para conocer del asunto, a que se le otorgue un tratamiento igual que el dado a otros particulares, a que el procedimiento se adelante en un término razonable (sin dilaciones injustificadas), a que las decisiones sean motivadas y a impugnar las mismas². Las altas cortes indican que a este tipo de trámites son aplicables -aunque de manera más flexible- los 
principios derivados derecho fundamental al debido proceso como el de presunción de inocencia, el de favorabilidad (principio in dubio pro administrado), el de legalidad de las sanciones y las penas, e -incluso- hay quienes enuncian que son aplicables los principios de tipicidad, antijuridicidad y culpabilidad de los hechos sancionados y de las sanciones, aunque adaptados a los fines del derecho administrativo ${ }^{3}$.

A pesar de la existencia de la garantía al debido proceso como principio rector del procedimiento sancionatorio contractual, el cual pareciese ser suficiente para resguardar los derechos a la defensa y a la seguridad jurídica del contratista, el procedimiento sancionatorio contractual descrito en el artículo 86 de la Ley 1474 de 2011 presenta un vacío en materia del procedimiento probatorio y de las garantías frente a la práctica de pruebas, que podría limitar el ejercicio efectivos de los derechos a la prueba, a la defensa y a la contradicción. Si bien la citada norma consagra el derecho de aportación y contradicción de las pruebas del contratista, nada dice acerca de cómo se surte la etapa de solicitud, práctica y valoración probatoria, ni sobre los derechos y garantías del contratista cuando se surten estas etapas. De ahí que la integración normativa queda a la discrecionalidad de las autoridades administrativas.

Al respecto, Letelier señala que las garantías que se prevén para los procedimientos sancionatorios tienen en cuenta que en estos no hay un verdadero litigio entre partes, ni hay razón para procurar una disminución de los falsos positivos (cuando se declara que había lugar a la sanción, pero no había lugar a ella), ni un riesgo a la privación de un derecho fundamental, como en el derecho penal ${ }^{4}$. El procedimiento sancionatorio contractual, no obstante, sí tiene como particularidad que el representante legal de la entidad o su delegado

3 Sentencia del Consejo de Estado, Sección Tercera, Subsección C, del 22 de octubre de 2012, radicación número: 05001-23-24-000-1996-00680-01(20738).

4 Letelier sostiene que las garantías previstas por el legislador tanto para las sanciones penales como para las administrativas son las que permiten diferenciar unas de las otras. Es por esta razón que, en su entender, aquella tendencia doctrinaria y jurisprudencial de transpolar las garantías del procedimiento penal a las garantías del procedimiento sancionatorio, sin mayor indicación que en este último se aplican con matices, tiene importantes efectos en el fin disuasorio que se buscan con las sanciones administrativas, al punto que dichos matices distorsionan los principios tal y como son concebidos en el derecho penal. Raúl LetelieR, "Garantías penales y sanciones administrativas", Polít. crim., vol. 12, n. $^{\circ} 24,2017$, p. 622,627 y 636, disponible en línea: http://www.politicacriminal.cl/Vol_12/n_24/Vol12N24A1.pdf. En Colombia, el principio que prescribe que el debido proceso se aplica a las actuaciones judiciales y administrativas es de carácter constitucional (artículo 29 de la Constitución Política), pero su alcance ha sido desarrollado por la jurisprudencia de las altas cortes y por la doctrina bajo el criterio de que las garantías penales son aplicadas a los procedimientos administrativos, incluyendo los sancionatorios, de manera matizada. 
actúan como juez y parte ${ }^{5}$, y que sus decisiones, presuntas de legalidad, pueden acarrear consecuencias graves al contratista como inhabilidades para contratar con el Estado ${ }^{6}$, y multas y sanciones cuantiosas. Tampoco puede olvidarse que la finalidad del legislador al consagrar la potestad sancionatoria contractual fue, entre otras, disuadir la corrupción en los contratos estatales (por ello se consagró en el estatuto anticorrupción) y que estos se ejecutaran a satisfacción. En la exposición de motivos del citado artículo 86 se evidencia que legislador pretendió otorgar un mecanismo ágil y eficaz para que las entidades apremien al cumplimiento de los contratos. Para lograr el efecto disuasorio buscado, la práctica y valoración de pruebas dentro de este procedimiento debe propender porque se conmine al cumplimiento de los contratos incumplidos, y se absuelva al contratista cumplido. Solamente los procedimientos sancionatorios que culminen con decisiones que se ajusten a la realidad sobre el cumplimiento de los contratos permitirán evitar su paralización y lograr el efecto preventivo previsto por el órgano parlamentario.

Esta situación manifiesta la importancia que el contratista cuente con las garantías probatorias necesarias para el ejercicio efectivo de sus derechos a la prueba y a la contradicción ${ }^{7}$. Máxime cuando la discrecionalidad sin límite

5 La calidad de juez y parte de la entidad contratante, al adelantar el procedimiento administrativo sancionador, se evidencia en el hecho de ser parte del contrato que da lugar al trámite sancionatorio. Pero además de que, con anterioridad a la expedición de la Ley 1150 de 2007, al no estar legalmente otorgada la potestad sancionatoria a las entidades públicas para la imposición de multas, sanciones y de cláusulas penales, cuando estas se hubieren pactado entre las partes de un contrato estatal en virtud de la autonomía de la voluntad debían ser cobradas por la entidad contratante al contratista acudiendo a la jurisdicción contenciosa administrativa, que era el juez natural del contrato. De manera que, el legislador, al haber otorgado a las entidades públicas una herramienta para la efectiva dirección y manejo de los contratos que celebren, optó por hacer una excepción al principio de igualdad de las partes en materia contractual, y otorgarle a una de ellas la calidad de juez y parte, atendiendo a que el propósito con la celebración del contrato es alcanzar los fines del Estado.

6 El artículo 90 de la Ley 1474 de 2011 establece inhabilidad para contratar con el Estado a quien haya sido objeto de cinco o más multas en una vigencia fiscal, o haya sido objeto de declaratoria de incumplimiento en dos contratos en una misma vigencia fiscal, o haya obtenido la imposición de dos multas y un incumplimiento en una misma vigencia fiscal. No en pocos casos se ve que las entidades en los pliegos de condiciones establecen como condición habilitante para participar en licitaciones públicas el no haber sido sancionado en cierto periodo de tiempo.

7 Letelier señala que en los procedimientos sancionatorios no se está ante un verdadero litigio entre partes, sino que la Administración actúa como ente inquisidor que, siendo su principal función y creada para la fiscalización, no tiene ninguna motivación o incentivo para considerar incumplido un sujeto que no lo es. Esta garantía, sumada al control por parte de lo contencioso administrativo, órgano diverso e independiente del que sancionó, disminuye la probabilidad de errores -ya sean de falsos positivos (casos en que se condena a una persona sin ser responsable), como de falsos negativos (aquellos en que no se condena al responsable)-. RAúL Letelier, "Garantías penales y sanciones administrativas", 
de la potestad sancionatoria puede promover la corrupción de los funcionarios y contratistas, dando al traste con la finalidad buscada por el legislador. Los pocos análisis jurisprudenciales y doctrinales en relación con el debido proceso probatorio en el procedimiento sancionatorio contractual hacen necesario una integración de las reglas y los principios consagrados en el Código de Procedimiento Administrativo y de lo Contencioso Administrativo (CPACA, Ley 1437 de 2011) y de aquellos que se desprenden del derecho al debido proceso del artículo 29 de la Constitución Nacional. Al realizar esta integración normativa se debe tener en cuenta las especiales connotaciones prácticas del procedimiento que nos ocupa. Esto permitirá fijar lineamientos en materia de aportación, práctica y valoración de las pruebas, que atiendan los derechos a la igualdad ante las entidades públicas y a la seguridad jurídica de los contratistas.

\section{EL PROCEDIMIENTO SANCIONATORIO CONTRACTUAL COMO HERRAMIENTA PARA ASEGURAR EL CUMPLIMIENTO DEL OBJETO CONTRATADO}

En el derecho colombiano, la contratación estatal es un mecanismo con el que las entidades públicas propenden por el cumplimiento de los fines del Estado y por una prestación continua y eficiente de los servicios públicos ${ }^{8}$. Para dichos propósitos, el legislador ha previsto que las entidades contratantes mantengan la dirección general del contrato, lo cual comprende la vigilancia y el control de su ejecución, con miras a su cumplimiento a satisfacción. Es por esto que el Estatuto General de la Contratación Pública (Ley 80 de 1993) y las normas que lo desarrollan prevén que las entidades del Estado cuenten con las herramientas suficientes para ejercer el control del contrato y evitar su paralización. Estas comprenden tanto las cláusulas excepcionales de la Administración (la terminación unilateral, la modificación unilateral, la interpretación unilateral y la declaratoria de caducidad del contrato), así como la potestad sancionatoria contractual otorgada a las entidades públicas contra el contratista incumplido. En virtud de esta potestad sancionadora, la Administración puede imponer

óp. cit., pp. 645 y 646 . El procedimiento sancionatorio contractual tiene, sin embargo, una característica peculiar, pues en este caso sí hay intereses contrapuestos en tratándose del contratante el ente sancionador, y que por ende sí puede tener motivaciones para condenar sin existir prueba suficiente de la responsabilidad del contratista; piénsese en los indicadores de gestión de la entidad o en los procedimientos contra los funcionarios de la entidad contratante por parte de los entes de control al observar retrasos en el cumplimiento del contrato que no son necesariamente imputables al contratista.

8 Juan Carlos Expósito Vélez, "Manifestaciones del debido proceso en el derecho administrativo sancionatorio contractual", en: Alberto Montaña Plata y Jorge Iván Rincón Córdoba, El poder sancionador de la Administración pública: discusión, expansión y construcción, Bogotá: Universidad Externado de Colombia, 2018, p. 489 
multas y sanciones, declarar el incumplimiento del contrato, tasar los perjuicios causados con el incumplimiento e imponer la cláusula penal pactada.

El artículo 4 de la Ley 80 de 1993 establece que las entidades públicas tienen el derecho y el deber de exigir el cumplimiento idóneo y oportuno del contrato, para lo cual deben adelantar las actuaciones tendientes al reconocimiento y cobro de las sanciones contractualmente pactadas. No obstante, se generó la inquietud en la doctrina acerca de si las multas, las sanciones y la cláusula penal se tenían como incorporadas de manera forzosa a los contratos regidos por el mencionado estatuto. Otro interrogante para los operadores jurídicos consistía en saber si, al no contemplarse dentro de las facultades exorbitantes de la Administración y al no referir de forma expresa la posibilidad de que las entidades contratantes pudieran imponer y cobrar de manera directa las sanciones y multas, aquellas debían acudir al juez natural del contrato para lograr su imposición al contratista9 .

La respuesta al primer interrogante fue dada por la remisión que hace dicho Estatuto a las normas de derecho privado, de manera que las partes del contrato pueden incorporar de mutuo acuerdo las cláusulas de multas, sanciones y cláusula penal por incumplimiento del contrato en virtud de la autonomía de la voluntad ${ }^{10}$. Frente al segundo cuestionamiento, el Consejo de Estado indicó que el principio de reserva de ley y el hecho de no contemplarse expresamente la potestad sancionadora de la Administración, hacía evidente que esta no tenía la facultad para imponer multas y sanciones, declarar el incumplimiento del contrato ni hacer efectiva la cláusula penal ${ }^{11}$. Es decir, que para su aplicación, las entidades públicas debían acudir ante la jurisdicción de lo contencioso administrativo. Con la expedición del artículo 17 de la Ley 1150 de 2007 se incorporó al ordenamiento jurídico la potestad de imponer multas y sanciones, declarar el incumplimiento y hacer efectivo su cobro de manera directa (a través de la compensación, la exigibilidad de la garantía o el cobro coactivo). La referida disposición previó que en su ejercicio se tuviera como principio rector la garantía al debido proceso y, por ende, la celebración de una audiencia que garantice el derecho de defensa del contratista, previo a la expedición del acto administrativo sancionatorio. Posteriormente, el artículo 86 de la Ley 1474 de 2011 estableció el procedimiento y las reglas mínimas que deben regir el ejercicio de la potestad sancionatoria contractual. Esta disposición contempla que, evidenciado un incumplimiento del contrato, la entidad pública debe realizar citación a audiencia en que se mencionen los

9 David Suarez Tamayo, Cláusulas de multas y penal pecuniaria, Medellín: Librería Jurídica Sánchez R. - Centro de Estudios de Derecho Administrativo, 2014, pp. 111-115.

10 Sentencia del Consejo de Estado, Sala de lo Contencioso Administrativo, Sección Tercera Subsección A, del 1. ${ }^{\circ}$ de febrero de 2018, radicación número: 25000-23-26-000-200900082-01(52549).

Ibíd. 
hechos que la soportan, las cláusulas contractuales incumplidas y las posibles sanciones a imponer. Dicha citación debe ir acompañada del informe de supervisión o interventoría en que se sustenta la actuación.

Por tanto, la Administración debe adelantar una audiencia única y concentrada en la que indicará al contratista los hechos que motivan la actuación, las normas u obligaciones presuntamente violadas, y las consecuencias que pueden derivarse del proceso sancionatorio que se adelanta. Por su parte, el contratista podrá formular descargos, aportar las pruebas que soportan su defensa y controvertir las que la entidad allegó. De acuerdo con la disposición contenida en el estatuto anticorrupción, en esa misma audiencia (que podrá ser suspendida para la práctica o aportación de pruebas que se consideren pertinentes), se deberá tomar la decisión acerca de la imposición de la multa, sanción o declaratoria de incumplimiento, contra lo cual procede el recurso de reposición. Asimismo, la norma establece las reglas a las que deben ceñirse las autoridades administrativas al ejercer la potestad sancionatoria. Ahora bien, la ausencia de normas precisas que regulen la solicitud, el decreto y las práctica de pruebas no permiten hacer efectiva la garantía al debido proceso probatorio de los contratistas.

\section{LAS GARANTÍAS PROBATORIAS DISPONIBLES DURANTE EL EJERCICIO DE LA POTESTAD SANCIONATORIA CONTRACTUAL}

El artículo 86 de la Ley 1474 prevé el derecho del contratista a la defensa, a presentar pruebas y a contradecir las que se alleguen en su contra. Es una expresión del derecho fundamental al debido proceso y a la prueba ${ }^{12}$ consagrado en la Constitución de 1991 que, en el marco del Estado social de derecho, suponen unas garantías fundamentales, por las que los servidores públicos deben propender ${ }^{13}$. El derecho a la prueba que contempla la mencionada norma debe analizarse en su contenido a la luz del artículo 29 de la Constitución Política de Colombia y del título I, "Disposiciones generales", del CPACA, a efectos de determinar su alcance y el de las garantías que comprende.

El núcleo esencial del derecho al debido proceso probatorio corresponde, según la Corte Constitucional, a:

12 Sentencia del Consejo de Estado, Sala de lo Contencioso Administrativo, Sección Tercera Subsección C, 21 de marzo de 2012, radicación número 11-001-03-26-000-2010-00060-00 (39477), y del Consejo de Estado, Sala de lo Contencioso Administrativo, Sección Tercera, Subsección C, 22 de octubre de 2012, radicación número 05001-23-24-000-1996-068001 (20738).

13 Ramón Antonio Peláez Hernández, La prueba ilícita desde la perspectiva de la regla de exclusión y su aplicación en el proceso civil, Bogotá: Universidad Externado de Colombia, 2017, pp. 80 y 101 . 
(i) el derecho para presentarlas y solicitarlas, (ii) el derecho para controvertir las pruebas que se presenten en su contra, (iii) el derecho a la publicidad de la prueba, pues de esta manera se asegura el derecho de contradicción, (iv) el derecho a la regularidad de la prueba, esto es, observando las reglas del debido proceso, siendo nula de pleno derecho la obtenida con violación de este, (v) el derecho a que de oficio se practiquen las pruebas que resulten necesarias para asegurar el principio de realización y efectividad de los derechos (arts. 2 y 228) y (vi) el derecho a que se evalúen por el juzgador las pruebas incorporadas al proceso ${ }^{14}$. (Sentencia C-496 de 2015) $)^{15}$.

Para el juez constitucional, la vulneración de estas garantías por omisión o errada valoración de pruebas, por la pretermisión de la etapa probatoria o por la valoración de pruebas ilícitas o ilegales puede dar lugar a la vulneración al derecho fundamental al debido proceso. A su vez, el CPACA normativiza a nivel de ley las garantías, los valores y los principios del debido proceso constitucional. Esto trae como consecuencia que se apliquen de manera directa, y no solamente como criterio hermenéutico, a todos los procedimientos administrativos que adelanten las autoridades públicas, aun cuando tengan normas de carácter especial que lo regulen, como sucede con el procedimiento sancionatorio contractual ${ }^{16}$.

Bajo esta perspectiva, el contratista, en un procedimiento sancionatorio contractual, cuenta con las mismas garantías probatorias que un investigado en cualquier otro procedimiento sancionatorio. Se destacan, por ejemplo, la garantía a que la decisión se fundamente en el análisis de las pruebas aportadas al proceso y, particularmente, en los hechos que resultaron probados (artículo 49 del CPACA). Los contratistas también cuentan con las garantías probatorias previstas para el procedimiento general (primera parte del CPACA) frente a la solicitud, aportación y contradicción de las pruebas. Se hace referencia al principio de legalidad y al derecho a que el procedimiento se adelante atendiendo las normas de procedimiento previamente previstas en la Constitución y la ley, como serían las relativas a las prácticas de las pruebas, con plena garantía de los derechos de defensa y contradicción, con observancia a los principios de presunción de inocencia, de imparcialidad (que adquiere especial relevancia frente a la práctica y valoración de las pruebas por parte de la autoridad administrativa), de publicidad de los actuaciones de la Administración (numeral 9, artículo 3 y numeral 2, artículo 5 ), de celeridad, economía y eficacia en la práctica de pruebas (numeral 11 a 13, artículo

14 Sentencia de la Corte Constitucional C-034 del 29 de enero de 2014, expediente D-9566. La cita es del texto original.

15 Sentencia de la Corte Constitucional C-496 del 5 de agosto de 2015, expediente D-10451.

16 Juan Manuel Laverde Álvarez, Manual de procedimiento administrativo sancionatorio, Bogotá: Legis, 2016. 
3), haciendo efectiva el derecho a presentar y aportar pruebas (numera 8 del artículo 5), a que estas sean oportunamente decretadas, salvo existencia y motivación de justa causa para su denegación (numeral 14, artículo 9) y a que las mismas sean valoradas y tenidas en cuenta al momento de expedir el acto administrativo sancionatorio (numera 8 del artículo 5).

Teniendo en cuenta lo expuesto, podría afirmare que las garantías probatorias mínimas con que cuenta el contratista dentro del procedimiento sancionatorio contractual corresponden a: a) presentar y solicitar pruebas; b) contradecir las pruebas que la entidad contratante presente en su contra; c) la garantía de publicidad de las pruebas que practica o aporta la entidad, y de sus soportes; d) la garantía de regularidad de la prueba; e) el derecho a contar con una oportunidad probatoria ${ }_{i}$ f) la garantía de inmediación en la práctica de las pruebas $;$ g) el derecho a que se decreten y practiquen las pruebas necesarias para la averiguación de la verdad, h) la garantía de evaluación y valoración de las pruebas incorporadas al procedimiento; e i) la garantía a la presunción de inocencia que, como se desarrollará más adelante, implica que la carga de la prueba corresponde a la entidad contratante que inicia el procedimiento sancionatorio. La aplicación práctica de la función integradora de los principios del debido proceso administrativo al ejercicio de la potestad sancionatoria $y$, particularmente, a las garantías probatorias en el proceso sancionatorio contractual permite una mayor claridad acerca de cómo deben las entidades públicas llevar a cabo el decreto, la práctica y la valoración de las pruebas. Por esta razón, el objeto del siguiente acápite es precisar el alcance y contenido de cada una de dichas garantías.

\subsection{El CONTENIDO DE LaS GaRANTías PROBATORIAS DEL PROCEDIMIENTO SANCIONATORIO CONTRACTUAL}

a. Derecho a presentar y a solicitar pruebas: El derecho a presentar y a solicitar pruebas en el procedimiento sancionatorio contractual está previsto en el Estatuto anticorrupción. Esta norma contempla que, una vez leídos los hechos que motivaron la apertura del procedimiento, el contratista y su garante pueden, directamente o a través de un apoderado, solicitar y aportar las pruebas que soporten su defensa ${ }^{17}$. De igual modo, se establece la posibilidad de suspender la audiencia para que, de oficio o a petición de la parte, se alleguen y practiquen las pruebas que a juicio del jefe de la entidad sean pertinentes y conducentes. Un mismo reconocimiento hace el $\mathrm{CPACA}^{18}$ al establecer que los particulares tienen derecho a aportar documentos u otros elementos de prueba en cualquier actuación administrativa en la cual tengan interés. 
Siendo el derecho a la prueba uno fundamental, autónomo y que constituye una de las principales garantías del derecho a la defensa ${ }^{19}$, es aplicable a todo tipo de procedimiento que puedan afectar derechos constitucionales ${ }^{20}$. Lo anterior es clave en la medida que en el procedimiento sancionatorio contractual el auto que decide sobre la admisibilidad de las pruebas no admite recurso alguno (artículo 40 del CPACA); de manera que la admisibilidad o negativa del decreto de las pruebas debe considerar la conducencia y pertinencia para la defensa del contratista, so pena de que puedan afectarse sus derechos a la defensa y al debido proceso ${ }^{21}$.

El procedimiento sancionatorio administrativo debe propender por la averiguación de la verdad. En este sentido, si un contratista está incumplido en sus obligaciones, así lo debe declarar la entidad contratante y proceder a imponer las multas y sanciones correspondientes. Asimismo, si el contratista cumplió con sus obligaciones contractuales, esto deberá reconocerse en el acto administrativo con que se archive el trámite. Esta finalidad puede verse limitada por el interés del contratista de ejercer su defensa, sin que esta necesariamente propenda por el esclarecimiento de la verdad ${ }^{22}$; o por los intereses particulares de la Entidad y sus funcionarios (piénsese en el cumplimiento de metas o en rendiciones de cuentas), situación que puede generar desavenencias con el contratista $^{23}$, que como juez-parte puedan limitar su imparcialidad. De ahí la importancia del efectivo ejercicio del derecho del contratista a pedir y aportar todas aquellas pruebas que considere pertinentes, conducentes y necesarias para sustentar la defensa planteada, y a que la entidad estudie su admisibilidad de manera neutral ${ }^{24}$. En este ejercicio, la autoridad administrativa deberá

19 Sentencia de la Corte Constitucional C-496 del 5 de agosto de 2015, expediente D-10626.

20 Luis Bernardo Ruiz JARAMILlo, El derecho constitucional a la prueba y su configuración en el Código General del Proceso colombiano (Tesis doctoral), Universitat Rovira I Virgili, Tarragona, 2017, p. 94 .

21 Sentencia de la Corte Constitucional T-393 del 7 de septiembre de 1994, expediente T-33308

22 Jordi Ferrer Beltrán, La valoración racional de la prueba, Madrid: Marcial Pons, 2007, p. 39.

23 Indica Ferrer que la verdad no es el único objetivo de la actividad probatoria y que se pueden tener muchos objetivos que incluso pueden entrar en conflicto entre sí, pudiendo generar la necesidad de que alguno de ellos deba postergarse en pro de algún otro. JORDI Ferrer Beltrán, Carmen Vásquez Rojas y Michele Tarufo, Teoría de la prueba, La Paz: Tribunal Constitucional Plurinacional, 2018, pp. 47-48. En el proceso sancionatorio contractual, la averiguación de la verdad puede ser simultánea a otros objetivos del proceso sancionatorio o de la entidad misma, no obstante, es nuestro criterio que en el mismo debe primar aque$1 l a_{i}$ de lo contrario, en vez de generar un efecto disuasorio, conminatorio o sancionatorio, puede tener el contrario, esto es, una disminución de particulares que quieran contratar y colaborar con la consecución de los fines del Estado, o un aumento de la corrupción en la contratación estatal al encontrar en esta el único mecanismo para evitar la imposición de multas y sanciones.

24 Toscano recuerda que el juez no puede abandonar sus prejuicios obtenidos de su experiencia en casos similares o de la presión mediática, ni mucho menos los sentimientos 
considerar que, si bien está en juego el interés general por que se cumpla el contrato, también lo está el esclarecimiento de la verdad como fin superior del Estado social de derecho.

Un aumento de los falsos positivos en este tipo de procedimientos conllevará a la imposición de sanciones injustas, e incluso a la vulneración de los derechos económicos constitucionales del contratista, derivados de la inhabilidad por incumplimiento reiterado (inhabilidad ante la imposición de cinco o más multas o de dos declaratorias de incumplimiento en dos contratos durante los últimos tres años, o de dos multas y una declaratoria de incumplimiento, en una misma vigencia fiscal $)^{25} ; \mathrm{o}$, incluso, la imposibilidad de presentar ofertas en licitaciones públicas en que se haya previsto como requisito habilitante el no haber sido sancionado en un cierto lapso de tiempo anterior a la convocatoria.

El derecho a presentar y a solicitar pruebas es además piedra angular de los derechos a la defensa y a la averiguación de la verdad, debiéndose garantizar plenamente para que el procedimiento sancionatorio contractual cumpla con su finalidad conminatoria y/o sancionatoria, y redunde en beneficio de la oferta de contratistas que tengan el interés y la capacidad de colaborar con el Estado en los fines que este debe alcanzar

b. Derecho a contradecir las pruebas que la entidad contratante presente en su contra: Corresponde al contratista el derecho a cuestionar las pruebas aportadas o decretadas de oficio con el citatorio o en el curso del procedimiento. El derecho de contradicción está estrechamente vinculado al del debido proceso, como lo indicó el Consejo de Estado al declarar nula una resolución proferida por la Beneficencia de Cundinamarca, por la cual se decretó la caducidad de un contrato de arrendamiento y se hizo efectiva la cláusula penal pactada, por considerar que la entidad contratante vulneró el derecho de contradicción del contratista al no permitirle presentar descargos, formular su defensa y contradecir los hechos que fundamentaban la decisión de la Administración. En la especie, el alto tribunal indicó que, aun cuando la Administración considere que el particular no tiene derecho sustantivo alguno que le dé la razón para evitar la sanción a imponer, ello no es óbice para que la Administración le niegue el derecho de contradicción, este

propios de la condición humana como la solidaridad, la animadversión y la empatía por alguna de las partes. Por esta razón, sugiere que la imparcialidad debe entenderse como el trato igualitario de las partes en el proceso y el deber del juez de asumir los hechos de manera desprevenida, sin asumir una posición anticipada del caso, para lo cual deberá contrarrestar sus prejuicios con el material probatorio a efectos de alcanzar la verdad sobre la cuestión que está decidiendo. Fredy HeRnando TosCano López, La imparcialidad en materia probatoria, Bogotá: Universidad Externado de Colombia, 2017. En igual sentido se expresa Ferrer, para quien la imparcialidad implica que el juez busque la verdad con independencia de a qué parte beneficie. Jordi Ferrer Beltrán, Carmen Vásquez Rojas y Michele TARufo, óp. cit., p. 41. 
no puede verse - menos hoy en día- como una formalidad cualquiera, que no afecta las decisiones administrativas ni los procedimientos al interior de los cuales se adopta, de lo contrario se relajaría excesivamente la protección al derecho fundamental al debido proceso, aduciendo que al fin y al cabo la administración o el juez no le darían la razón al ciudadano ${ }^{26}$.

Durante la práctica y contradicción de la prueba se admiten distintos controles por parte de la Administración y del contratista. Sugiere Ferrer que uno de dichos controles es el que se efectúa sobre la admisibilidad de las pruebas, mediante la participación de las partes en la práctica de la prueba de manera contradictoria, la oportunidad de proponer pruebas que desvirtúen o corroboren la hipótesis planteada en el caso y la posibilidad de presentar o solicitar pruebas que controviertan la fiabilidad de las pruebas; todo en aras de enriquecer el material probatorio desde el punto de vista cualitativo ${ }^{27}$. Advierten Vásquez y Álvarez que esta garantía debe extenderse a todos los momentos del procedimiento, incluyendo las fases previas a la investigación y las posteriores al juicio. Así, el informe de interventoría o de supervisión que debe allegar la entidad junto con la citación al procedimiento sancionatorio contractual debe poder controvertirse por el contratista ${ }^{28}$.

En aquellos casos en que el interventor o supervisor han practicado pruebas para sustentar su informe, el contratista puede acceder y contradecir las pruebas practicadas directamente por aquellos, aun cuando las mismas no se practiquen durante el procedimiento. Si por ejemplo la interventoría advierte problemas de calidad de una obra contratada y decide, para soportar su informe de requerimiento a la entidad de declaratoria de incumplimiento, practicar una prueba técnica que determine las causas de las fallas de la obra, la entidad contratante tendrá el deber de dar la oportunidad al contratista para que evalúe los procedimientos bajo los cuales se adelantó la prueba practicada por la interventoría, conozca los documentos a los que tuvo acceso el experto para rendir su dictamen o concepto, y a contradecir los procedimientos y conclusiones a las que este llegó al practicar la prueba. Desconocer el derecho de contradicción de las pruebas vulnera el debido proceso y puede dar lugar a la anulación del acto administrativo sancionatorio. Incluso podría dar lugar a que el juez de tutela ${ }^{29}$, como mecanismo transitorio para evitar un perjuicio irremediable, ampare la garantía del contratista dejando, incluso, sin efectos

26 Sentencia de Consejo de Estado, Sala de lo Contencioso Administrativo, Sección Tercera Subsección C, 12 de agosto de 2014, radicación número 25000-23-26-000-1998-02424$01(27.246)$.

27 Jordi Ferrer Beltrán, óp. cit., pp. 87-89

28 Jean Paul Vásquez Gómez y Lilia Yaneth Álvarez Quiroz, El debido proceso en las actuaciones administrativas contractuales sancionatorias, Medellín: Librería Jurídica Sánchez R., 2018, p. 138.

29 Corte Constitucional, sentencia T-796 del 21 de septiembre 2006, expediente T-1330716. 
actos administrativos cuando la entidad no ha corrido traslado de los dictámenes periciales o de sus aclaraciones y complementaciones, pretermitiendo la posibilidad de objetarlos ${ }^{30}$.

c. La garantía de publicidad de las pruebas que practica o aporta la entidad, y de sus soportes: Los derechos fundamentales y las garantías que estos envuelven son la mejor expresión de los principios que regulan el ordenamiento jurídico ${ }^{31}$. Así, la publicidad como garantía fundamental del derecho a la prueba de los contratistas es una manifestación del debido proceso probatorio sancionatorio contractual. El derecho a la publicidad de la prueba tiene dos connotaciones. Una individual, frente al contratista investigado, y una social. La primera de ellas es indispensable para el ejercicio del derecho de defensa y contradicción, al exigir que todos los actos que adelante la Administración, incluso frente a la práctica de pruebas, deban ser conocidos por el contratista. La segunda permite a la sociedad conocer el contenido de las pruebas practicadas para que efectúe un control social de las decisiones ${ }^{32}$. La garantía de publicidad no solo se concreta durante el curso del procedimiento, sino en el acto administrativo que decide el procedimiento y su motivación. Es aquí donde se puede verificar si la decisión de la entidad fue debidamente sustentada y razonada con base en el material probatorio obrante en el expediente ${ }^{33}$. Laverde plantea, de manera acertada, que en virtud de esta garantía, los administrados tienen derecho incluso a conocer los documentos que tienen el carácter de reservado y que sirven de sustento a la actuación administrativa ${ }^{34}$. De manera que el derecho a la publicidad de las pruebas en que la entidad soporta su decisión permite no solo un efectivo ejercicio de derecho de defensa del contratista al presentar descargos, sino para oponerse a la decisión mediante el recurso de reposición contra el acto administrativo sancionatorio, e incluso en el marco del control de legalidad que demande ante la jurisdicción de lo contencioso administrativo.

d. Garantía de regularidad de la prueba: Esta garantía está estrechamente vinculada al principio de legalidad por cuanto las pruebas que se decreten y practiquen deben observar las reglas establecidas por el legislador para su práctica

30 Indica Ruiz Jaramillo que, si bien la Corte Constitucional ha reconocido el derecho a la prueba como un derecho fundamental y autónomo, aunque integre el contenido del debido proceso, lo cierto es que la tutela constitucional siempre se ha concedido cuando su vulneración afecta el debido proceso. Luis Bernardo Ruiz JARAMILLO, óp. cit., pp. 96-97.

31 " [...] mandatos de optimización que ordenan que algo sea realizado en la mayor medida de lo posible, de acuerdo a las posibilidades fácticas y jurídicas que juegan en sentido contrario". Robert Alexy en Carlos Bernal Pulido, El derecho de los derechos, Bogotá: Universidad Externado de Colombia, 2005, p. 96.

32 Ramón Antonio Peláez Hernández, óp. cit., p. 111.

33 Jairo ParRa Quijano, Manual de derecho probatorio. Bogotá: Librería Ediciones del Profesional 2006, p. 10.

34 Juan Manuel Laverde Álvarez, óp. cit., p. 92. 
en debida forma ${ }^{35}$. Si bien no existe una regulación normativa específica para la práctica de las pruebas en el procedimiento sancionatorio contractual, es posible afirmar que por remisión del artículo 40 del CPACA se puedan solicitar, aportar, admitir y practicar todos los medios de pruebas admisibles por el Código General del Proceso, y para su práctica deberán seguirse las disposiciones de dicho estatuto. El constituyente previó que la vulneración a las reglas previstas para la práctica de una prueba tiene como consecuencia que -por vulnerarse el debido proceso- esta se torne nula de pleno derecho y deba ser excluida del trámite. Ciertamente, el artículo 29 de la Constitución 1991, al elevar el derecho a la prueba a rango ius fundamental, estableció que la nulidad de la prueba no solo se genera por la pretermisión de término para la práctica y contradicción de la prueba, sino incluso cuando su práctica no sea efectiva y material, atendiendo las formalidades previstas por el legislador para ello. De manera que la prueba obtenida o practicada con violación al debido proceso, que no sea declarada nula y excluida del procedimiento, hace posible que el juez constitucional tutele esta garantía mediante la declaración de nulidad del acto administrativo sustentado en pruebas ilegales ${ }^{36}$.

e. Garantía de oportunidad probatoria: La garantía de oportunidad probatoria está relacionada con el momento en que el contratista puede solicitar y aportar pruebas, y con el momento hasta cuando la entidad puede decretar las pruebas pedidas de parte o de oficio. Esta garantía se encuentra íntimamente ligada al derecho a presentar y solicitar pruebas, pero obedece más a la oportunidad en que este derecho puede ejercerse. De acuerdo con el artículo 86 de la Ley 1474 de 2011, el contratista tiene derecho a solicitar pruebas y aportar las que considere pertinentes. Agrega que el jefe de la entidad o su delegado podrá suspender la audiencia para allegar o practicar pruebas, caso en el cual debe señalar fecha y hora para reanudar la audiencia. Esta redacción podría dar a entender que la solicitud de pruebas puede darse en cualquier momento hasta antes de tomarse la decisión por parte de la entidad contratante, más genera la pregunta de si pueden solicitarse y practicarse durante el trámite del recurso de reposición.

La interpretación de la disposición en relación con el momento en que se puede solicitar, decretar y aportar pruebas al proceso debe ser afín con el objetivo de la averiguación de la verdad, de manera que permita maximizar la información disponible en el proceso. No existe razón epistemológica ni de política pública que permita afirmar fundadamente que las pruebas pueden solicitarse y practicarse solo hasta antes de la decisión del jefe de entidad y no durante el trámite del recurso contra la misma. Entender que las pruebas 
no pueden aportarse durante el trámite de reposición del acto administrativo sancionatorio resulta una interpretación restrictiva frente al querer del legislador, y vulnera el ejercicio del derecho a la prueba y con ello la defensa del investigado. El procedimiento sancionatorio contractual prevé que en la misma audiencia se deben presentan descargos, aportar y practicar pruebas, y decidir sobre la imposición de multas y sanciones. Esta disposición podría llevar a la administración a tomar decisiones aun cuando no cuenten con una cantidad suficiente de información relevante para tomar la decisión ${ }^{37}$. Es posible interrogarse si los principios de celeridad, eficacia y economía que debe guiar el procedimiento (según los cuales las actuaciones administrativas deben estar dirigidas a alcanzar los fines del Estado, buscando el mayor beneficio, con el menor costo posible, en recursos y en cuanto al tiempo se refiere) entran en conflicto con el de oportunidad probatoria. Si bien la Administración debe procurar que la audiencia sea lo más célere posible, la misma norma prevé la posibilidad de suspender la audiencia. Esta opinión coincide con aquella de Vásquez y Álvarez, quienes afirman que, por remisión a las disposiciones que regulan el procedimiento sancionatorio general, la práctica de pruebas puede realizarse en un término no mayor a treinta días, o a sesenta si se trata de más de tres investigados o si las pruebas deben practicarse en el exterior ${ }^{38}$. Ante la tensión entre el derecho a contar con una oportunidad probatoria acorde con el esclarecimiento de la verdad, que se acompase con el principio de interpretación favorable al que aluden Vásquez y Álvarez, de un lado, y el derecho a que se decida en una sola audiencia atendiendo los principios de economía, eficacia y celeridad, resulta exigible que la entidad contratante, en el caso concreto, aplique los mencionados principios en la mayor medida de lo posible, para que una vez tenga una cantidad de elementos suficientes y relevantes tome una decisión fundada en información de calidad.

f. Derecho a que se decreten y practiquen las pruebas necesarias para la averiguación de la verdad: Para la efectividad del derecho del contratista a aportar y contradecir las que se le presenten en contra, aun mediante la práctica de otras pruebas, es necesario que aquel intervenga en el ejercicio de decreto y práctica probatoria. Si bien el procedimiento sancionatorio contractual nada establece sobre la admisibilidad de las pruebas, el literal d del artículo 86 señala que es posible que la entidad suspenda la audiencia cuando en "su criterio" sea necesario para allegar o practicar pruebas que "estime conducentes y pertinentes". De esta disposición se infiere que el funcionario que dirige la actuación tiene la posibilidad de decretar o negar las pruebas de manera motivada y sustentada en la conducencia y pertinencia de las pruebas que la parte le solicite o aporte; que incluso la declaratoria de pruebas de oficio debe considerar dichos 
criterios. Esta garantía está protegida en los procedimientos administrativos a nivel constitucional tal como lo ha reconocido la jurisprudencia de la Corte Constitucional. Precisa la Corte que la entidad solo puede negarse a la práctica de pruebas cuando estas no contribuyan al esclarecimiento de la verdad en el litigio que se plantea (son impertinentes), cuando estén prohibidas, sean ineficaces o sean superfluas, al ya existir suficiente material probatorio en el expediente. No obstante, tales motivos deben ser evidentes y debidamente sustentados por la entidad ${ }_{i}$ y ante la duda, deberá preferirse su admisibilidad, ante el riesgo manifiesto de negar una prueba necesaria para el ejercicio del derecho de defensa ${ }^{39}$. Lo anterior revela el deber de la entidad pública de motivar suficientemente los actos administrativos que deciden sobre la solicitud de pruebas, principalmente, con base en el criterio que Ferrer denomina de relevancia (o pertinencia), en el sentido de indicar por qué aquellas pruebas, cuya práctica deniega, no permiten fundar una conclusión respecto de los hechos que se pretenden probar. En cuanto a la exclusión de pruebas manifiestamente superfluas o inútiles (artículo 168 Código General del Proceso), señala la Corte que el legislador quiso que la redundancia de una prueba, y la consecuente negativa de la administración a que aquella se practique, fuese evidente o manifiesta ${ }^{40}$.

Toda vez que el criterio de inutilidad de la prueba puede ser restrictivo y violatorio del derecho de defensa, debe aplicarse de manera acorde al objetivo de búsqueda de la verdad. Para este propósito, nos parece prudente una formulación como la propuesta por Ferrer, quien sostiene que toda vez que la corroboración de una hipótesis nunca es absoluta, entonces nuevas pruebas (ya sea del mismo tipo o que corresponda a otro medio de prueba) siempre serán relevantes, hasta tanto el grado de corroboración que estas puedan aportar sea mínimo, caso en el cual estará justificada la exclusión o negativa de la práctica de las mismas. Las anteriores consideraciones no pueden perderse de vista por la administración, pues en los procedimientos administrativos no se admite recurso alguno contra los actos que niegan o admiten una prueba (salvo algunas voces que indican que, en virtud del principio de la interpretación más favorable, el recurso de reposición es procedente contra el auto que decide sobre el decreto y práctica de pruebas). De ahí que, como indica la Corte, la Entidad debe evitar negar las pruebas solicitadas por los investigados o sus garantes $y_{\text {, }}$ ante la duda, preferir su admisión y práctica, propendiendo así por la verdad ${ }^{41}$.

g. Garantía de inmediación en la práctica de las pruebas: La garantía de inmediación en la práctica de las pruebas se refiere al contacto directo que debe tener el jefe de la entidad, o quien este designe para adelantar el procedimiento 
sancionatorio, con las pruebas durante su práctica y contradicción. Si bien esta garantía no aparece de forma expresa en la norma, se deduce de la previsión del legislador de que el trámite debe adelantarse en una sola audiencia oral, en la que se escuche al contratista y su garante en descargos, y se permita la práctica de pruebas aportadas y solicitadas por estos ${ }^{42}$. Otra razón que permite sostener que el contratista cuenta con la garantía de la inmediación del juez con las pruebas es que el Código de Procedimiento Administrativo no establece normas que regule la delegación de la práctica de pruebas a otros funcionarios de la misma u otra entidad pública. Esta garantía permite, además, que la autoridad administrativa realice un control de la fiabilidad de las pruebas que se practican, aun cuando no a la valoración de estas ${ }^{43}$. Lo anterior resulta necesario en un procedimiento en el que la entidad actúa como juezparte, y cuyo propósito es la búsqueda de la verdad y el interés general por el cumplimiento de los fines del Estado. Esto permite sugerir que los jefes de las entidades públicas deben delegar el ejercicio de la potestad sancionatoria en un funcionario formado en el área del derecho, o en alguien asesorado por el área jurídica de la entidad. El control de la fiabilidad probatoria y el proceso de valoración de pruebas, conforme a los criterios de razonabilidad y de la sana crítica, requiere una formación en materia de garantías constitucionales al debido proceso y del derecho a la prueba, y un conocimiento sobre la valoración, motivación y sustentación de actos administrativos; de ahí la importancia de tener en cuenta los conocimientos y experiencia del funcionario en que se delega tal función.

h. Garantía de evaluación y valoración de las pruebas incorporadas al procedimiento: En sentencia C-499 de 2015, la Corte Constitucional, al estudiar la exequibilidad de la expresión "cuantificando los perjuicios del mismo", contenida en el artículo 86 de la Ley 1474 de 2011, se pronunció sobre el deber de las autoridades que ejercen la potestad sancionatoria de sustentar sus decisiones en la valoración

42 La norma consagra que el procedimiento sancionatorio administrativo, en principio, debe desarrollarse en una sola audiencia, que solo puede suspenderse por una razón debidamente justificada o para la práctica de pruebas, que garantice el correcto desarrollo del trámite. No obstante, esta pretensión parece de difícil cumplimiento, no solo porque en el mayor de los casos deberán practicarse las pruebas que se soliciten, sino porque una valoración de estas de manera inmediata y sin una debida racionalización, puede conllevar a que las decisiones se tomen sin fundamento o desconociendo las reglas de la lógica y de la experiencia que dicha valoración requiere. De ahí que en muchas ocasiones las entidades otorguen, aunque la norma no lo prevea, una oportunidad al contratista para que presente alegatos, y suspendan la audiencia para valorar lo ocurrido en el curso del trámite y decidir a su reanudación. Por esto, más que el trámite se desarrolle en una sola audiencia, se sugiere que la misma se efectúe de manera concentrada, es decir, en un lapso corto, que permita al representante legal o su delegado que participe de manera directa en todas las pruebas y relacionar todas las inferencias que resulten del material probatorio. 
de las pruebas practicadas en el proceso. En dicha oportunidad, el cargo que le correspondió a la Corte analizar fue si el legislador, al atribuir a la entidad estatal la competencia para tasar perjuicios en el contexto de un procedimiento administrativo contractual, vulneraba la presunción de buena fe (artículo 83 de la CP), el derecho al debido proceso (artículo 29 de la CP), y el principio de prevalencia del derecho sustancial sobre las formalidades (artículo 228 de la $\mathrm{CP})$. Al respecto, la Corte indicó que el procedimiento consagrado por el legislador garantiza el debido proceso. La referida corporación resaltó que, si bien la buena fe se presume en las relaciones de los particulares con la Administración, dicha presunción admite prueba en contrario y que la resolución sancionatoria debe ser el resultado de la valoración de las pruebas debidamente aportadas al proceso. En este sentido, afirmó que

dado que la resolución motivada en comento debe fundarse en hechos verificados por medio de pruebas, no en suposiciones y prejuicios de la entidad estatal, lo que significa que tanto la existencia de perjuicios derivados del incumplimiento del contrato como la responsabilidad del contratista en ellos debe estar probada, en el escenario de la audiencia, la actuación administrativa en la que se soporta la cuantificación de perjuicios respetan el debido proceso [sic].

La valoración probatoria completa la triada que hacen efectivo el ejercicio del derecho fundamental a la prueba, junto con la posibilidad de aportar todas las pruebas que sean pertinentes a los hechos que se pretenden probar y a que las mismas se practiquen. Si la autoridad administrativa no valora las pruebas ni funda su decisión en los hechos que resultan probados en el procedimiento sancionatorio, vaciaría de contenido dicha garantía ${ }^{44}$. Valorar, indica Gascón Abellán, significa evaluar la veracidad de las hipótesis desde el punto de vista de las pruebas obrantes en el expediente, determinar el soporte probatorio con que cuentan las hipótesis en conflicto dentro del trámite y decidir cuál de las hipótesis otorga un grado de probabilidad suficiente respecto de los hechos planteados en el mismo ${ }^{45}$. La garantía de valoración probatoria en el procedimiento sancionatorio contractual tiene fundamento en la exigencia de que el acto administrativo decisorio sea motivado. El numeral 8 del artículo 5 del Código de Procedimiento Administrativo indica que los particulares tienen derecho a que los elementos de prueba sean valorados y tenidos en cuenta al momento de decidir.

La valoración en Colombia, indica el artículo 176 del Código General del Proceso, se rige por el sistema libre de valoración de la prueba. La libre valoración implica que el juzgador obtenga la convicción de su decisión y de

45 Marina Gascón Abellán, Cuestiones probatorias, Bogotá: Universidad Externado de Colombia, 2002, pp. 464, 484 y 502. 
las pruebas que la soportan, en las reglas de la sana crítica, en citerior de sana lógica, reglas de la experiencia o racionales ${ }^{46}$. Para estos efectos, la autoridad debe valorar individualmente cada uno de los elementos de juicio que obran en el expediente, indicar -de manera lógica y razonada- el mérito que le corresponde a cada uno de estos, y valorar de manera conjunta y en contexto las pruebas ${ }^{47}$. Por lo demás, la motivación de la resolución, valorando los cargos, los medios de prueba practicados y las hipótesis plateadas por la interventoría o el supervisor en el informe con base en el cual se da apertura al procedimiento, por el contratista en el ejercicio de su derecho de defensa y por su garante, es una garantía de racionalidad de la decisión frente a la arbitrariedad de las autoridades ${ }^{48}$.

i. La carga objetiva de la prueba corresponde a la entidad que ejerce la potestad sancionatoria: La Corte Constitucional y la doctrina colombiana han manifestado unánimemente que, en los procesos sancionatorios, el administrado tiene derecho a todas las garantías del debido proceso, aunque más flexibles que en el proceso penal, e incluso la correspondiente a gozar de la presunción de inocencia ${ }^{49}$. Indica Expósito Vélez que la flexibilización de estas garantías se exige para dar cumplimiento a los principios de eficiencia, eficacia, celeridad y economía que rigen el procedimiento administrativo, sin que ello signifique su inaplicabilidad ${ }^{50}$. La pregunta que surge es cómo se manifiesta la presunción de inocencia en el procedimiento sancionatorio contractual. De igual manera, Letelier manifiesta que la presunción de inocencia en el derecho sancionador puede ser entendida en el sentido clásico del derecho penal que imparte un estándar de prueba para sancionar muy alto, o como la ausencia de una presunción de responsabilidad. Sin embargo, en su concepto, resulta más apropiado no relativizar el concepto clásico de la presunción de inocencia, sino comprender la normatividad administrativa sancionadora a la luz de sus fines ${ }^{51}$.

46 Daniel González Lagier, Apuntes sobre prueba y argumentación jurídica, Alicante: Repositorio institucional de la Universidad de Alicante, 2014, p. 32. Disponible en línea: http://hdl. handle.net/10045/37145 [consultado el 27 de marzo de 2020].

47 Jordi Ferrer Beltrán, óp. cit., p. 45.

48 Indica Gascón que la motivación debe ocuparse de la valoración de absolutamente todas las pruebas que fueron practicadas dentro del proceso, y no solo de aquellas que sustentan la decisión del juez. Es decir, si la sentencia es condenatoria, la motivación debe considerar las razones por las cuales se desestimaron las pruebas que sustentaban una decisión absolutoria, y viceversa. Agrega que además implica la valoración de las pruebas sobre hechos secundarios, es decir, aquellos necesarios para establecer la verdad de la premisa objeto del litigio. Marina GasCón Abellán, óp. cit., pp. 1576, 1724 y 1734.

49 Corte Constitucional, sentencias C-980 del 1. ${ }^{\circ}$ de diciembre de 2010, expediente D-8104, y C-248 del 24 de abril de 2013, expediente D-9285.

50 Juan Carlos Expósito Vélez, óp. cit., pp. 472 y 477-478.

51 Para Letelier, la presunción de inocencia en el ámbito del derecho sancionador puede entenderse en el sentido clásico en que se manifiesta en el derecho penal en el sentido de fijar un estándar alto de prueba, o como la ausencia de una presunción de responsabilidad. 
La garantía del contratista es la existencia de una presunción de responsabilidad. Implica, además, que el Estado, en cabeza de la entidad pública que ejerce la potestad sancionatoria, debe probar ${ }^{52}$ los hechos que constituyen el fundamento de la infracción y la imputabilidad de aquel frente a dicha actuación ${ }^{53}$. Si de lo que se trata es de la declaratoria de incumplimiento del contrato, la Administración deberá probar que el contratista era titular de la obligación que se dice incumplida y la inejecución de esta imputable al contratista. Si además de la declaratoria de incumplimiento se pretende la tasación de perjuicios, la Administración pública deberá probarlos ${ }^{54}$, salvo que se trate de hacer efectiva la cláusula penal, caso en el cual la misma deberá tasarse con criterios de razonabilidad y proporcionalidad, teniendo en cuenta el porcentaje de cumplimiento del contrato ${ }^{55}$.

Algunos funcionarios públicos aducen que en el procedimiento sancionatorio contractual se contempla una inversión de la carga de la prueba. En su decir, al consagrarse en el artículo 86 de la Ley 1474 de 2011 que "Evidenciado un posible incumplimiento de las obligaciones a cargo del contratista, la

Raúl Letelier, "Garantías penales y sanciones administrativas", óp. cit., pp. 642-543. En nuestro concepto, es en este último sentido como debe entenderse la presunción de inocencia como principio del derecho sancionador. El estándar de prueba -entendido como la cantidad de prueba requerida en un proceso para que el juzgador considere que resultan procedente aplicar las consecuencias jurídicas del supuesto de hecho correspondiente- no puede ser tan alto en el derecho sancionador contractual como en un proceso penal. Esto porque los intereses jurídicos protegidos no son los mismos y por cuanto las sanciones penales pueden coartar libertades constitucionales que tienen una mayor relevancia constitucional (la libertad) que aquellos que eventualmente pueden afectarse con las multas y sanciones procedentes en aquel.

52 En el Código General del Proceso, la carga de la prueba se entiende como una regla según la cual incumbe a las partes probar el supuesto de hecho de las normas que consagran el efecto jurídico que ellas persiguen. En el procedimiento administrativo sancionador a la entidad contratante le incumbe probar que el administrado incumplió sus obligaciones contractuales o incurrió en una infracción en el marco del contrato que lo hace acreedor de una sanción (por ejemplo, una infracción ambiental); por su parte, al contratista le incumbe probar que los hechos aducidos por la administración no existen o no le son imputables. Distinta es la concepción de la carga de la prueba propuesta por Ferrer, quien señala que esta regla permite determinar quién gana o pierde el proceso si no se logra alcanzar el estándar de prueba previsto para el correspondiente proceso. Atendiendo a esta consideración del profesor Ferrer consideramos que en el procedimiento sancionatorio contractual, si no se alcanza el estándar de prueba requerido para sancionar el contratista, es la Administración quien debe abstenerse imponer la sanción. Jordi Ferrer Beltrán, óp. cit.

53 Sentencia del Consejo de Estado, Sala de lo Contencioso Administrativo, Sección Tercera Subsección C, del 22 de octubre de 2012, radicación número 05001-23-24-000-19960680-01 (20738).

54 Sentencia de la Corte Constitucional C-499 del 5 de agosto de 2015, expediente D-10626.

55 Sentencia del Consejo de Estado, Sala de lo Contencioso Administrativo, Sección Tercera, Subsección C, del 13 de noviembre de 2008, radicación número 68001-23-31-000-199602081-01(17009). 
entidad pública lo citará a audiencia para debatir lo ocurrido", le corresponde al administrado desvirtuar el informe de interventoría o del supervisor en el que la entidad pública soporta la citación al procedimiento, y probar el cumplimiento del contrato para lograr el archivo del procedimiento o una resolución declarando la improcedencia de la sanción. Frente a los contratos de obra también refieren que se aplica por remisión de la Ley 80 de 1993 las normas civiles, particularmente los artículos 2059 y 2060 del Código Civil, los cuales regulan la ejecución indebida de una obra material y de edificios, en las que -en su concepto- se establece una presunción de culpa y de responsabilidad. Una interpretación en tal sentido desconoce los principios que regulan la actuación administrativa, en particular el numeral 1, artículo 3 del $\mathrm{CPACA}_{\text {, }}$ que de manera expresa consagra el principio de presunción de inocencia en los procedimientos administrativos.

El procedimiento sancionatorio contractual tiene un carácter sui generis pues en realidad lo que se sanciona es el incumplimiento de un contrato, trasladándose la decisión sobre la responsabilidad contractual a una de las partes. Por ello, estamos de acuerdo con que la aplicación de las disposiciones civiles y comerciales a los contratos estatales está contemplada por remisión del artículo 13 del Estatuto Nacional de la Contratación, que deberán aplicarse por la entidad contratante al momento de evaluar la responsabilidad del contratista. Deberá entonces considerarse, verbi gratia, los artículos 2059 y 2060 del Código Civil, y ante una presunta falla en la obra contratada, nombrar de mutuo acuerdo a peritos técnicos en quienes se delegue la definición de si la obra se ejecutó de forma indebida. Si las partes no han logrado ponerse de acuerdo en que sea un perito técnico quien defina si la obra se ha ejecutado conforme a las normas técnicas que rigen el contrato, la entidad deberá decidirlo en la resolución motivada, debidamente soportada en pruebas. En este caso, el artículo 2060 del Código Civil establece una presunción de culpa del contratista $^{56}$, que en todo caso admitirá prueba en contra de la diligencia o cuidado con la que ha actuado, o de que los hechos acaecieron por una fuerza mayor o un caso fortuito que permite.

Se anota que la presunción de culpa solo opera en los procedimientos administrativos sancionatorios, cuando el legislador así lo ha dispuesto

Así lo señala Fernando Hinestrosa en los siguientes términos: "Por último, cabe anotar que en las obligaciones de hacer el incumplimiento puede manifestarse en términos de ejecución imperfecta, $[\ldots]$ cuando quiera que $[\ldots]$ la obra no se ajuste a los términos del modelo trazado en el título, con las características correspondientes a las exigencias técnicas y profesionales del desempeño del operario [...] Respecto de la prueba, se ba dicho que la ejecución defectuosa o imperfecta jamás constituye una negación o afirmación indefinida, sino un becho positivo, concreto y, por lo tanto, susceptible de prueba [...] probada por el actor la ejecución defectuosa de la obligación, la culpa del deudor demandado se presume". Fernando Hinestrosa, Tratado de las obligaciones, concepto, estructura y vicisitudes, 3. ${ }^{a}$ ed., Bogotá: Universidad Externado de Colombia, 2007, p. 240 (bastardillas fuera del original). 
expresamente, como acontece en el contrato de obra según lo expuesto previamente, o en el procedimiento sancionatorio ambiental (Ley 1333 de 2009). De lo contrario, el principio de presunción de inocencia asigna a la entidad la carga de los elementos de la responsabilidad, esto es, el hecho generador (el incumplimiento de una obligación contractual), el daño, perjuicio o deterioro, y la imputabilidad de estos al contratista, a título de dolo o culpa ${ }^{57}$. Una cosa es la garantía que aquí hemos esbozado, y otra distinta el estándar de prueba que debe exigirse en este tipo de procedimientos que consideramos que no puede ser tan alto como el establecido en el derecho penal constituido por el "más allá de toda duda razonable". Concordamos con Letelier acerca de que un estándar de prueba como el previsto en el derecho civil, esto es, la prueba preponderante, consistente en que la hipótesis de la ocurrencia de la infracción imputable al administrado resulta más razonable o probable que otra hipótesis es la que debe aplicarse al procedimiento sancionatorio y, en el caso que nos ocupa, al de naturaleza contractual. En palabras de Letelier, "El hecho se entenderá probado de acuerdo con esta regla cuando la probabilidad de que haya acaecido es simplemente mayor a que no ${ }^{\prime 58}$. Teniendo en cuenta que el procedimiento sancionatorio se inicia soportado en un informe de la interventoría o del supervisor del contrato, quienes tienen el deber de efectuar un seguimiento financiero, técnico y jurídico de este, las preguntas que surgen recaen sobre la naturaleza de este informe: ccorresponde a otra prueba dentro del material probatorio?, ¿constituye una prueba de tipo técnico? y cestando soportada la actuación en el informe de la interventoría que aduce la existencia de un posible incumplimiento, nos encontramos ante una presunción de responsabilidad que el contratista tiene la carga de desvirtuar? Para lo anterior, es preciso hacer un breve estudio acerca del papel que tiene el informe de interventoría o del supervisor, en el marco del procedimiento sancionatorio contractual.

57 Sentencia del Consejo de Estado, Sala de lo Contencioso Administrativo, Sección Tercera Subsección C, del 22 de octubre de 2012, radicación número 05001-23-24-000-19960680-01 (20738).

58 Raúl Letelier, óp. cit., pp. 641-642. Para Letelier, exigir un estándar de prueba distinto al de prueba preponderante permite reducir al máximo el número de falsos positivos como el de falsos negativos; mientras que si se fija un estándar de prueba distinto se favorecerá el aumento de falsos positivos frente a la disminución de falsos negativos o viceversa, pues no es posible empeorar uno de los elementos sin que el otro esté mejor. RAúL LETELIER, "El precio del statu quo. Sobre el estándar probatorio en las sanciones administrativas", Revista de Derecho, vol. XXI, n. ${ }^{\circ} 1,2018$, p. 219. 


\section{EL INFORME DE INTERVENTORÍA O DE SUPERVISIÓN QUE DEBE ALLEGARSE CON LA CITACIÓN AL PROCEDIMIENTO SANCIONATORIO CONTRACTUAL: ¿UNA PRUEBA MÁS DENTRO DEL CONJUNTO DEL MATERIAL PROBATORIO?}

De acuerdo con el artículo 83 de la Ley 1474 de 2011, la supervisión de un contrato consiste en el seguimiento técnico, financiero, administrativo, jurídico y contable, que un funcionario de la entidad contratante realiza al cumplimiento del objeto de los contratos públicos. En algunos casos, la entidad puede contratar la interventoría para que un supervisor efectúe el seguimiento técnico financiero, administrativo, jurídico y/o contable del contrato, siempre que las funciones del supervisor y del interventor no concurran. La contratación de una interventoría se necesitará cuando esta labor requiera de conocimientos especializados o por la complejidad o extensión del contrato ${ }^{59}$. Para efectos del seguimiento del cumplimiento del contrato y de las obligaciones a cargo del contratista, el supervisor y el interventor tienen la facultad y el deber de solicitar información al contratista sobre el estado del contrato, hacer advertencias o dar instrucciones sobre la ejecución del contrato, en el marco de los manuales de supervisión e interventoría de cada entidad, del manual de funciones del servidor público, y del contrato de interventoría. Sin embargo, la responsabilidad más importante que tienen los supervisores e interventores de un contrato consiste en mantener informada a la entidad contratante acerca del estado de cumplimiento del contrato, y sugerir el inicio de procedimientos sancionatorios cuando advierta el incumplimiento contractual ${ }^{60}$.

El Código General Disciplinario (Ley 1952 de 2019), norma que regula la responsabilidad de los funcionarios públicos y de los particulares que ejerzan funciones públicas, señala dentro de las faltas relacionadas con la contratación pública que el supervisor o interventor del contrato omitan el deber de informar a la entidad contratante los hechos o circunstancias que puedan constituir actos de corrupción tipificados como conductas punibles, o que puedan poner o pongan en riesgo el cumplimiento del contrato, o del incumplimiento del mismo. Este último supuesto de hecho de la norma podría dar a entender que el informe de interventoría que advierta sobre el incumplimiento del contrato constituye prueba plena y absoluta sobre el incumplimiento del contratista, invirtiendo la carga de prueba para que sea este quien demuestre que ejecutó a cabalidad sus obligaciones contractuales. Por consiguiente, cuando contratos del Estado, Bogotá: Colombia Compra Eficiente, p. 5. Disponible en línea: https:// www.colombiacompra.gov.co/sites/cce_public/files/cce_documents/cce_guia_para_el_ejercicio_de_las_funciones_de_supervision_e_interventoria_de_los_contratos_del_estado.pdf. Ibíd. pp. 8-9. 
el Código Disciplinario prevé el deber de los supervisores e interventores de rendir informe a la entidad contratante cuando "se presente el incumplimiento", incurre en una imprecisión gramatical. Lo anterior, por cuanto la potestad sancionatoria está en cabeza del jefe de la entidad contratante o de quien este delegue, sin que los interventores o supervisores puedan suplir a la entidad en las decisiones que versen sobre el contrato vigilado, ni sobre la determinación de imponer sanciones al contratista, y mucho menos en la declaración de incumplimiento. El informe de interventoría es tan solo una advertencia del posible incumplimiento en que puede estar el contratista, y no una prueba definitiva del incumplimiento. Tampoco puede afirmarse que dicho informe genera una inversión de la carga de la prueba, o hace presumir el incumplimiento del contratista que este está en el deber de desvirtuar. Una presunción de dicho tipo debe estar expresamente prevista en la norma, y no puede deducirse por interpretación.

Una vez iniciado el procedimiento sancionatorio, el informe de supervisión y/o de interventoría que soporta su apertura y las pruebas allegadas junto con este serán parte del material probatorio que de manera individual y en conjunto debe valorar el jefe de la entidad o su delegado para determinar la responsabilidad del contratista. Aun cuando el informe de supervisión y/o de interventoría provenga de un experto en la materia objeto del contrato y que pueda considerarse que esta tiene la calidad de una prueba técnica, lo cierto es que la entidad deberá valorar la fiabilidad de la prueba, los soportes en los que el informe se sustenta e incluso las pruebas indirectas que pretendan poner en duda la credibilidad del informe (como podría ser, eventualmente, la prueba enemistad o falta de profesionalismo de la interventoría con el contratista). En algunos casos la interventoría en el marco de su contrato puede tener la obligación de elaborar pruebas y ensayos sobre la ejecución efectuada por el contratista, los cuales pueden servir de soporte al informe que rinda sobre el incumplimiento o el retraso del contrato. Incluso en estos casos, la entidad tendrá el deber de ponerlos a disposición del contratista para que este pueda controvertir, si es el caso, los procedimientos, los resultados y hasta las calidades técnicas de los profesionales que las llevaron a cabo.

En materia jurisprudencial, no existe en el Consejo de Estado unidad de criterio sobre la naturaleza epistémica del informe de interventoría. Una primera posición se evidencia en la sentencia de la Sección Tercera, Subsección B, del 5 de noviembre de 2016, que señaló que la entidad contratante asegurada debe probar el daño, perjuicio o deterioro y la imputabilidad de estos al contratista. Según esta sentencia, la prueba de la imputación debe obedecer a una prueba técnica, no a una simple prueba de inspección visual, que evidencie el defecto constructivo o la inobservancia por parte del contratista de las condiciones inicialmente fijadas en el contrato que comportara ruina o deterioro de las 
obras $^{61}$. La citada providencia coloca la carga de la prueba en cabeza de la entidad contratante, por ende, debe garantizarse el principio de presunción de inocencia del administrado. En dicha oportunidad se declaró no probada la excepción de presunción de legalidad del acto administrativo presentada por la entidad pública demandada, quien alegaba que este se soportó en el informe y el diagnóstico de la vía elaborado por una consultoría contratada. La citada corporación encontró probado en el proceso que dicho diagnostico era apenas una inspección visual que determinó que, entre muchas, la causa de las fallas de la obra pudo haber sido el incumplimiento de los requerimientos técnicos contratados, sin que hubiese certeza de que esta fuese la única causa determinante generadora del daño.

En la sentencia del 30 de agosto de $2018^{[62]}$ se advierte una segunda posición, de la cual nos apartamos, en relación con el valor epistémico que se les otorga a los informes de supervisión o interventoría. En esta sentencia se declaró la nulidad del acto administrativo de imposición de multas al no haberse permitido el ejercicio del derecho de contradicción, y haberse pretermitido la oportunidad de aportar o solicitar pruebas que desvirtuaran los informes de interventoría. Sin embargo, indica que, pese a estar probada la violación al debido proceso, no existía falsa motivación del acto, pues el contratista "no acreditó su propio cumplimiento", por ende, no tenía la Sala pruebas "que desvirtúen los informes rendidos por el interventor [...] y que acrediten que sí se ejecutaron las labores contratadas en los terrenos que la contratista tuvo a su disposición". Esta sentencia parece desconocer el principio de presunción de inocencia que gobierna los procedimientos sancionatorios, así como la consecuencia que este impone relativa a que, ante la falta de pruebas sobre la responsabilidad del contratista, este no puede resultar sancionado. Pese a la vacilación que tiene la jurisprudencia del Consejo de Estado sobre este aspecto, el derecho de defensa, el derecho a aportar y a controvertir pruebas, la garantía de publicidad de las actuaciones de la entidad, el derecho a una valoración del conjunto de pruebas obrantes en el expediente, y el principio de presunción de inocencia, nos permite afirmar que el informe de interventoría y/o de supervisión constituye uno de los hechos probatorios, dentro de todo el conjunto de pruebas, que pueden y deben practicarse en el trámite. El material probatorio debe ser valorado en conjunto para determinar si está

61 Si bien el litigio versó sobre la declaratoria del siniestro, que la jurisprudencia ha señalado que no constituye un procedimiento sancionatorio contractual, sino un procedimiento para hacer efectiva la calidad de un contrato, es posible hacer referencia a esta sentencia, pues en el procedimiento sancionatorio como en el de declaratoria de siniestro, se debe determinar la veracidad de los hechos, el daño o afectación, y la imputabilidad de estos al contratista.

62 Sentencia del Consejo de Estado, Sala de lo Contencioso Administrativo, Sección Tercera, Subsección B, del 30 de agosto de 2018, radicación número 1998-01143/37935. 
suficientemente probado que el contratista ha incumplido el contrato y es procedente la imposición de multas, sanciones o declaratoria de incumplimiento con tasación de perjuicios, o hacer efectiva la cláusula penal.

\section{CONCLUSIONES}

La falta de claridad sobre las garantías y los derechos probatorios de los contratistas que envuelve el debido proceso para el procedimiento sancionatorio contractual puede imponer límites a la averiguación de la verdad, máxime si se tiene en cuenta que en este procedimiento la entidad contratante actúa como juez y parte, que pueden generar sesgos, prejuicios o intereses al resolver sobre la imposición de multas, sanciones o decidir sobre el cumplimiento de un contrato. La interpretación e integración normativa frente a las garantías y los derechos probatorios realizados permiten establecer unos criterios que, sin limitar la discrecionalidad otorgada por el legislador a los funcionarios que ejercen la potestad sancionadora, propenden por un procedimiento más justo para los contratistas y permiten hacer efectivo su derecho a la igualdad de trato ante las entidades públicas. Es evidente que el contratista, en cualquier etapa del procedimiento, e incluso durante el trámite del recurso de reposición contra la decisión de la Administración, tiene derecho a presentar todos los medios probatorios permitidos en el Código General del Proceso, a contradecir las que la entidad presente en su contra y a tener acceso a los documentos y soportes de las pruebas aportadas por esta o practicadas dentro del trámite. En consecuencia, la decisión de negar la práctica de pruebas debe estar debidamente sustentada y motivada en la falta de pertinencia o relación con el objeto investigado dentro del procedimiento.

En virtud del principio de presunción de inocencia y de favorabilidad que rige el procedimiento sancionatorio contractual, la carga de la prueba de la existencia de la obligación contractual y del incumplimiento o del supuesto de hecho que da lugar a la imposición de la multa o sanción corresponde a la entidad contratante. El informe de la interventoría o supervisor del contrato, que la entidad debe allegar junto con la citación al procedimiento, no consagra una inversión de la carga de la prueba del incumplimiento que el contratista deba desvirtuar, sino otra prueba dentro del conjunto del material probatorio que se debe valorar en conjunto para determinar la responsabilidad del contratista. Esto debería aportar mayor seguridad jurídica frente a la aplicación de las garantías del debido proceso en relación con la conformación, práctica y valoración del material probatorio en el procedimiento sancionatorio contractual. Sin embargo, será el ejercicio de la potestad sancionatoria por las entidades y el control que de esta realice la jurisdicción de lo contencioso lo que permitirá la mayor efectividad del derecho al debido proceso probatorio, para que este procedimiento pueda cumplir con el objetivo propuesto por el 
legislador; esto es, que sirva de herramienta contra la corrupción y permita a la Administración mantener el control de los contratos estatales.

\section{BIBLIOGRAFÍA}

\section{DOCTRINA}

Bernal Pulido, Carlos. El derecho de los derechos. Bogotá: Universidad Externado de Colombia, 2005.

Colombia Compra Eficiente. Guía para el ejercicio de las funciones de Supervisión e Interventoría de los contratos del Estado. Bogotá: Colombia Compra Eficiente. Disponible en línea: https://www.colombiacompra.gov.co/sites/cce_public/files/cce_documents/ cce_guia_para_el_ejercicio_de_las_funciones_de_supervision_e_interventoria_de_los_contratos_del_estado.pdf.

Expósito Vélez, Juan Carlos. "Manifestaciones del debido proceso en el derecho administrativo sancionatorio contractual". En Alberto Montaña Plata y Jorge Iván Rincón Córdoba, El poder sancionador de la Administración pública: discusión, expansión y construcción. Bogotá: Universidad Externado de Colombia, 2018.

Ferrer Beltrán, Jordi, Carmen Vásquez Rojas, Tarufo, Michele. Teoría de la prueba. La Paz: Tribunal Constitucional Plurinacional, 2018.

Ferrer Beltrán, Jordi. La valoración racional de la prueba. Madrid: Marcial Pons, 2007.

Gascón Abellán, Marina. Cuestiones probatorias. Bogotá: Universidad Externado de Colombia, 2002.

Gonzalez Lagier, Daniel. Apuntes sobre prueba y argumentación jurídica. Alicante: Repositorio institucional de la Universidad de Alicante, 2014. Disponible en línea: http:// hdl.handle.net/10045/37145 [consultado el 27 de marzo de 2020].

Hinestrosa, Fernando. Tratado de las obligaciones, concepto, estructura y vicisitudes, 3. a ed. Bogotá: Universidad Externado de Colombia.

Laverde Álvarez, Juan Manuel. Manual de procedimiento administrativo sancionatorio. Bogotá: Legis, 2016.

Letelier, Raúl. "El precio del statu quo. Sobre el estándar probatorio en las sanciones administrativas". Revista de Derecho, vol. XXI, n. . . 1, 2018.

Letelier, Raúl. "Garantías penales y sanciones administrativas". Polít. crim., vol. 12, n. ${ }^{\circ} 24,2017$. Disponible en línea: http://www.politicacriminal.cl/Vol_12/n_24/ Vol12N24A1.pdf. 
Parra Quijano, Jairo. Manual de derecho probatorio. Bogotá: Librería Ediciones del Profesional, 2006.

Peláez Hernández, Ramón Antonio. La prueba ilícita desde la perspectiva de la regla de exclusión y su aplicación en el proceso civil. Bogotá: Universidad Externado de Colombia, 2017.

Ruiz Jaramillo, Luis Bernardo. El derecho constitucional a la prueba y su configuración en el Código General del Proceso colombiano (Tesis doctoral), Universitat Rovira I Virgili, Tarragona, 2017.

Suarez Tamayo, David. Cláusulas de multas y penal pecuniaria. Medellín: Librería Jurídica Sánchez R. - Centro de Estudios de Derecho Administrativo 2014.

Toscano López, Fredy Hernando. La imparcialidad en materia probatoria. Bogotá: Universidad Externado de Colombia, 2017.

Vásquez Gómez, Jean Paul, Álvarez Quiroz, Lilia Yaneth. El debido proceso en las actuaciones administrativas contractuales sancionatorias. Medellín: Librería Jurídica Sánchez R., 2018.

Jurisprudencia de la Corte Constitucional

Sentencia de la Corte Constitucional T-393 del 7 de septiembre de 1994, expediente T-33308.

Sentencia de la Corte Constitucional, T-796 del 21 de septiembre 2006, expediente T-1330716.

Sentencia de la Corte Constitucional C-980 del 1. ${ }^{\circ}$ de diciembre de 2010, expediente D-8104.

Sentencia de la Corte Constitucional C-248 del 24 de abril de 2013, expediente D-9285.

Sentencia de la Corte Constitucional C-496 del 5 de agosto de 2015, expediente D-10451.

Sentencia de la Corte Constitucional C-499 del 5 de agosto de 2015, expediente D-10626.

\section{Jurisprudencia del Consejo de Estado}

Sentencia del Consejo de Estado, Sala de lo Contencioso Administrativo, Sección Tercera, Subsección C, del 13 de noviembre de 2008, radicación número 6800123-31-000-1996-02081-01(17009). 
Sentencia del Consejo de Estado, Sala de lo Contencioso Administrativo, Sección Tercera, Subsección C, 21 de marzo de 2012, radicación número 11-001-03-26000-2010-00060-00 (39477).

Sentencia del Consejo de Estado, Sala de lo Contencioso Administrativo, Sección Tercera, Subsección C, del 22 de octubre de 2012, radicación número 05001-2324-000-1996-0680-01 (20738).

Sentencia de Consejo de Estado, Sala de lo Contencioso Administrativo, Sección Tercera, Subsección C, 12 de agosto de 2014, radicación número 25000-23-26000-1998-02424-01 (27.246).

Sentencia del Consejo de Estado, Sala de lo Contencioso Administrativo, Sección Tercera, Subsección A, del 1. ${ }^{\circ}$ de febrero de 2018, radicación número: 25000-2326-000-2009-00082-01(52549).

Sentencia del Consejo de Estado, Sala de lo Contencioso Administrativo, Sección Tercera, Subsección B, del 30 de agosto de 2018, radicación número 1998-01143/37935. 